\title{
The improved photostability of naproxen in the inclusion complex with 2-hydroxypropyl- $\beta$-cyclodextrin
}

\author{
Snežana S. Ilić-Stojanović ${ }^{1}$, Vesna D. Nikolić ${ }^{1}$, Ljubiša B. Nikolić ${ }^{1}$, Aleksandar S. Zdravković ${ }^{2}$, \\ Agneš J. Kapor ${ }^{3}$, Mirjana M. Popsavin ${ }^{4}$, Slobodan D. Petrović ${ }^{5}$ \\ ${ }^{1}$ University of Niš, Faculty of Technology, Leskovac, Serbia \\ ${ }^{2}$ College of Textile, Leskovac, Serbia \\ ${ }^{3}$ University of Novi Sad, Faculty of Sciences, Department of Physics, Novi Sad, Serbia \\ ${ }^{4}$ University of Novi Sad, Faculty of Sciences, Department of Chemistry, Novi Sad, Serbia \\ ${ }^{5}$ University of Belgrade, Faculty of Technology and Metallurgy, Belgrade, Serbia
}

\begin{abstract}
The aim of this work was the preparation of the inclusion complex of naproxen with 2hydroxypropyl- $\beta$-cyclodextrin (HP- $\beta-C D$ ) in order to improve the physical and chemical properties of naproxen. The molecular inclusion complexes of naproxen with HP- $\beta-C D$ were prepared by using the co-precipitation method in the solid state with the molar ratio of $1: 1$. The structure of the obtained complex was characterized by using FTIR, ${ }^{1} \mathrm{H}$ NMR, UV-Vis and XRD methods. The testing of naproxen photostability by the UV-Vis method indicated the degradation to aromatic ketone, 2-acetyl-6-methoxynaphthalene. FTIR analysis showed that the degradation has started 15 days after the exposure of naproxen to daylight while the inclusion complex of naproxen:2-hydroxypropyl- $\beta$-cyclodextrin was photostable for a period of 30 days.
\end{abstract}

Keywords: naproxen, photodegradation, 2-hydroxypropyl- $\beta$-cyclodextrin, inclusion complex.

\author{
SCIENTIFIC PAPER \\ UDC 615:547:543.5 \\ Hem. Ind. 69 (4) 361-370 (2015) \\ doi: 10.2298/HEMIND131128050I
}

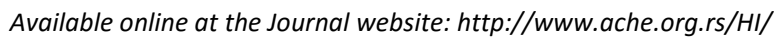

Naproxen, (+)-(S)-2-(6-methoxynaphthalen-2-yl)propanoic acid, is a derivative of 2-arylpropionic acids (profen drugs) which, in therapeutic doses, reduces the biosynthesis of prostaglandin and fever [1]. It exhibits anti-inflammatory and analgesic effects, relieves the symptoms of rheumatic diseases and other conditions accompanied by inflammation and the acute pain of moderate severity. Of two enantiomers of naproxen only the $S$-form is active.

Naproxen is a photosensitive and low soluble molecule which can be degraded under the influence of light by giving pharmacologically inactive products. A great number of published works were presented in the ways to improve the solubility of naproxen. For the improved solubility Mura and colleagues developed solid naproxen and chitosan systems [2,3] and triple systems of naproxen, amino acids and hydroxypropyl- $\beta$-cyclodextrin [4]. Various synthetic polymers were used as drug carriers in order to achieve the efficient and targeted delivery systems for a satisfactory therapeutic application. Agglomerated crystals of naproxen with hydroxypropyl cellulose improved the compactness [5]. A diblock copolymer of poly(ethylene- $\beta$-methacrylic acid) (PEO- $\beta$-PMAA) was synthesized by the atom transfer

Correspondence: S.S. Ilić-Stojanović, Faculty of Technology, University of Niš, Bulevar oslobođenja 124, 16000 Leskovac, Serbia.

E-mail: ilic.s.snezana@gmail.com; ilicsnezana@tf.ni.ac.rs

Paper received: 28 November, 2013

Paper accepted: 17 June, 2014 radical polymerization and applied to the $\mathrm{pH}$-dependent release of naproxen embedded into the core of the micelle [6]. The obtained results provided the potential use of the PEO- $\beta$-PMAA micelle system for a targeted delivery of various hydrophobic drugs in the small intestine. The interactions of poly(vinylpyrrolidone) (PVP) with ibuprofen and naproxen were also studied [7]. The influence of the drug on the glass transition, solubility and specific types of hydrogen bonding interactions were analyzed [8].

Cyclodextrins and their derivatives are suitable drug carriers because their molecule can host another substance in its cavity. The inclusion complex of naproxen with $\beta$-cyclodextrin increased the solubility and the drug release rate $[9,10]$. The interactions in inclusion complexes of $\alpha$-cyclodextrin, $\beta$-cyclodextrin, $\gamma$-cyclodextrin and dimethyl- $\beta$-cyclodextrin with naproxen, ibuprofen and panadol were examined [11]. The inclusion complexes of cyclodextrin and its derivatives were used to improve the physical and chemical properties of the drugs (solubility, vapor, odor, stability, etc.). A great number of researches proved that the solubility and stability of the drugs are increased, e.g., atenolol [12-14], nifedipine, nicardipine [15-17], amlodipine $[18,19]$ and allicin [20]. The solubility of the usnic acid was improved by complexation with $\beta$-cyclodextrin ( $\beta$-CD:UA) which is incorporated in liposomes [21].

It was observed that naproxen absorbed UV irradiation up to $360 \mathrm{~nm}$ and, in the presence of oxygen, lead 
to its direct degradation. As a result of photodegradation, the obtained molecules were more hydrophobic with the increased toxicity which, compared to naproxen [22], reduced the pharmacological activity and safety of the drug administration. Photodegradation products of naproxen include 4-isobutylacetophenone, 1-(6-methoxy-2-naphthyl)ethanol and 2-acetyl-6-methoxynaphthalene. Both keto analogues of naproxen belonged to the group of aromatic ketones, that presence increases the rate of photodegradation during the light exposure. Aromatic ketones moved the molar absorptivity towards higher wavelengths and consequently acted as more photosensitive agents [23]. A recent research showed the improved photostability of the usnic acid and piroxicam in the inclusion complexes with 2-hydroxypropyl- $\beta$-cyclodextrin (HP- $\beta$-CD) $[24,25]$.

The aim of this work was the preparation of the inclusion complex of naproxen with HP- $\beta-C D$, its structural characterization and the naproxen photosensitivity enhancement. The molecular inclusion complex based on naproxen and $\mathrm{HP}-\beta-\mathrm{CD}$, as a complexing agent, was prepared by the chemical co-precipitation method in the solid state and in the molar ratio of $1: 1$. For the structural characterization of the complex, a complexing agent, naproxen, the corresponding physical mixture of naproxen and HP- $\beta-C D$, the methods of nuclear magnetic resonance $\left({ }^{1} \mathrm{H}-\mathrm{NMR}\right), \mathrm{X}$-Ray diffraction (XRD) and Fourier transform infrared spectrometry (FTIR) were used. For the investigation of the impact in the photostability of naproxen, the FTIR method and ultraviolet and visible spectroscopy (UV-Vis) were used for the analysis of photosensitive groups of naproxen in a pure and complexed form.

\section{EXPERIMENTAL}

\section{Material and methods}

Naproxen was supplied from Megafine Pharma Ltd. (99.67\% purity), while 2-hydroxypropyl- $\beta$-cyclodextrin (97\%) and potassium bromide (spectroscopic grade) were supplied from Merck, Darmstadt. Other solvents and reagents used were of p.a. purity.

\section{Preparation of inclusion complex}

The inclusion complex of naproxen:2-hydroxypropyl- $\beta$-cyclodextrin was obtained by the co-precipitation method with the molar ratio of the reactants $1: 1$. The measured amounts of naproxen $(230.259 \mathrm{mg}$ ) and 2-hydroxypropyl- $\beta$-cyclodextrin (1541.54 mg) were suspended in distilled water $\left(150 \mathrm{~cm}^{3}\right)$. The solution was mixed at room temperature for $48 \mathrm{~h}$, protected from the light. In order to carry out the dissolution and due to the poor solubility of naproxen, the prepared solution was then subjected to ultrasound for $1 \mathrm{~h}$. The ultrasound device Sonic (Niš, Serbia), and an ultrasonic bath with the dimensions $\mathrm{A}: \mathrm{B}: \mathrm{H}=300 \mathrm{~mm} \times 151$ $\mathrm{mm} \times 200 \mathrm{~mm}$, with $8 \mathrm{dm}^{3}$ volume, were used under the following conditions: the temperature $30^{\circ} \mathrm{C}$, the ultrasound wave frequency $40 \mathrm{kHz}$ and the power of $150 \mathrm{~W}$, the total nominal power of $3 \times 50 \mathrm{~W}$. After the treatment by ultrasound, this solution was evaporated in a vacuum evaporator at $50{ }^{\circ} \mathrm{C}$ protected from the light, to the volume of approximately $20 \mathrm{~cm}^{3}$, and then dried in a desiccator above the concentrated sulfuric acid at $25{ }^{\circ} \mathrm{C}$. After drying, a white crystalline complex was obtained and as such it was used for further investigations in this work.

\section{Preparation of physical mixture}

Physical mixtures were prepared by simple mixing of naproxen with 2-hydroxypropyl- $\beta$-cyclodextrin as complex agents in the mole ratio of $1: 1$.

\section{Fourier transform infrared spectrometry (FTIR)}

FTIR spectra of the samples were recorded by using the technique of thin transparent pills with potassium bromide, spectroscopic purity, under vacuum at the pressure of $200 \mathrm{MPa}$. Using this method, the following was analyzed: naproxen, 2-hydroxypropyl- $\beta$-cyclodextrin, the inclusion complex naproxen:2-hydroxypropyl- $\beta$-cyclodextrin and a physical mixture of naproxen and 2-hydroxypropyl- $\beta$-cyclodextrin with the measured 150 $\mathrm{mg} \mathrm{KBr}$ and $0.2 \mathrm{mg}$ samples. $\mathrm{KBr}$ tablets, with naproxen and the complex naproxen:2-hydroxypropyl- $\beta$-cyclodextrin, were exposed to daylight and, in certain time intervals, FTIR spectra were recorded.

For all the samples, the recording was carried out in the area of wave numbers from 4000 to $400 \mathrm{~cm}^{-1}$ on the FTIR spectrophotometer Bomem Hartmann \& Braun MB-series. The spectra were processed by using the Win-Bomem Easy software.

\section{Nuclear magnetic resonance spectrometry $\left({ }^{1} \mathrm{H}-\mathrm{NMR}\right)$}

${ }^{1} \mathrm{H}$-NMR spectra of the samples of the inclusion complex naproxen:hydroxypropyl- $\beta$-cyclodextrin, 2-hydroxypropyl- $\beta$-cyclodextrin and naproxen were made on the Bruker AC 250 E NMR spectrometer with operating frequencies of $250 \mathrm{MHz}$, in a $5 \mathrm{~mm}$ diametar glass cuvette at room temperature. $\mathrm{D}_{2} \mathrm{O}$ was used as a solvent.

\section{$X$-ray diffraction (XRD)}

X-ray diffraction was performed on the Phillips PW 1030 powder diffractometer by exposing the samples to monochrome CuK $\alpha$ radiation, $\lambda=1.54178 \AA$, and analyzed under the angle $2 \theta$ between 5 and $45^{\circ}$ with $0.05^{\circ}$ increments and recording time, $\tau=5 \mathrm{~s}$. The voltage and the strength of the electric current were $40 \mathrm{kV}$ and $20 \mathrm{~mA}$, respectively. 


\section{Ultraviolet and visible spectrophotometry (UV-Vis)}

The sample was prepared by dissolving $2.5 \mathrm{mg}$ of naproxen in $10 \mathrm{~cm}^{3}$ of distilled water. The quartz glass cuvette of dimensions $1 \mathrm{~cm} \times 1 \mathrm{~cm} \times 4.5 \mathrm{~cm}$ was used. The recordings were performed in the wavelength range of 200-800 nm using the Varian Cary 100 spectrophotometer while distilled water was used as a blind test.

\section{RESULTS AND DISCUSSION}

The structural characterization of the obtained molecular inclusion complex naproxen:2-hydroxypropyl- $\beta$-cyclodextrin, a complexing agent, naproxen and the corresponding physical mixtures were carried out by FTIR, ${ }^{1} \mathrm{H}-\mathrm{NMR}, \mathrm{XRD}$ and UV-Vis methods. For monitoring the formed photodegradation products of naproxen, FTIR and UV-Vis methods were applied. XRD diffraction patterns of naproxen, 2-hydroxypropyl- $\beta$ -cyclodextrin, the physical mixture and the inclusion complex naproxen:2-hydroxypropyl- $\beta$-cyclodextrin are shown in Figure 1.

The comparative analysis of XRD diffraction patterns (Fig. 1) was used to observe the difference at some peaks in the diffraction patterns of the complex naproxen:2-hydroxypropyl- $\beta$-cyclodextrin, naproxen, 2-hydroxypropyl- $\beta$-cyclodextrin and the physical mixture of naproxen and 2-hydroxypropyl- $\beta$-cyclodextrin. Diffractogramm of 2-hydroxypropyl- $\beta$-cyclodextrin (Fig. 1 , data d) had two wide peaks with the maxima at 11.7 and $18.5^{\circ}$ which did not show clearly defined reflec- tions and the disordered crystal structure corresponded to the amorphous structure. The presence of well-structured sharp peaks with the maxima at 6.5, 12.6, 13.4, 16.6, 18.0, 18.8, 19.9, 20.6, 22.1, 22.5, 23.5, 23.9 and $28.2^{\circ}$ with clearly defined reflections in the XRD diffractogram of naproxen (Fig. 1, data c) confirmed its crystalline structure. In the XRD diffractogram of the physical mixture of naproxen and 2-hydroxypropyl- $\beta$-cyclodextrin (Fig. 1, data a) characteristic peaks of naproxen with the maxima at $6.6,12.6,18.9$, 20.6, 22.5 and $23.5^{\circ}$ and wide peaks with the maximum at 11.7 and $18.5^{\circ}$ derived from 2-hydroxypropyl- $\beta$-cyclodextrin were present. The results of the physical mixture indicated that there was no molecular interaction between the molecules of the guest and the host, i.e., the diffraction of the physical mixture presented the sum of diffraction patterns of naproxen and 2-hydroxypropyl- $\beta$-cyclodextrin. The diffraction pattern of the inclusion complex of naproxen:2-hydroxypropyl- $\beta$ -cyclodextrin did not contain the peaks that are characteristic for diffractograms of naproxen and HP- $\beta$-CD. The loss of the peaks at $6.5,13.4,16.6,18.0,19.9,21.1$, 23.9 and $28.2^{\circ}$, and the peaks with the reduced intensity present at $12.6,18.8,20.6,22.5$ and $23.5^{\circ}$, which originated from naproxen in the diffraction pattern of the inclusion complex of naproxen:2-hydroxypropyl- $\beta$ -cyclodextrin (Fig. 1, data b), indicated that the drug molecules were protected from $\mathrm{X}$-rays by the inclusion of the guest molecules in the hydrophobic cavities of the host molecule.

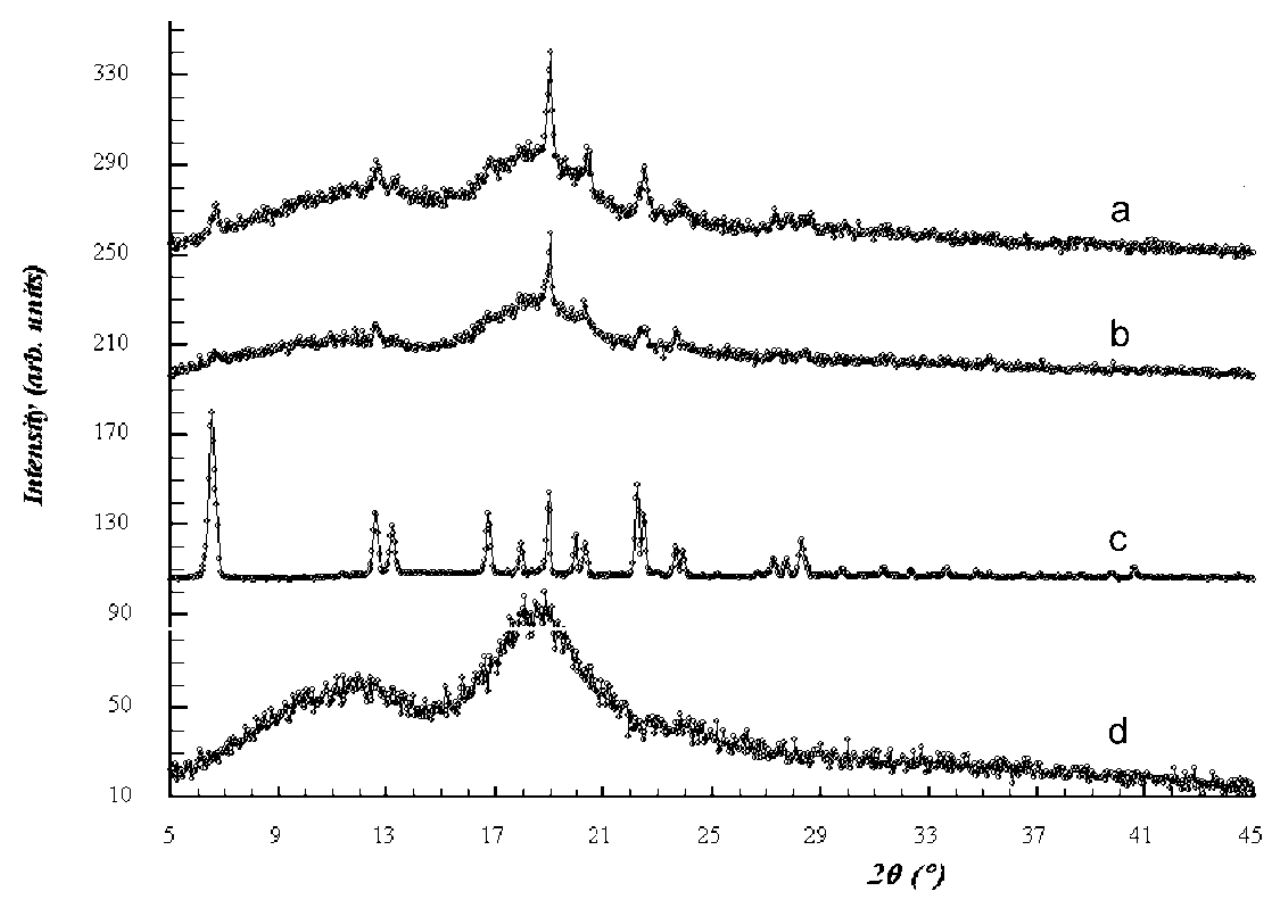

Figure 1. XRD diffraction: physical mixture of naproxen and 2-hydroxypropyl- $\beta$-cyclodextrin (a), inclusion complex naproxen:2-hydroxypropyl- $\beta$-cyclodextrin (b), naproxen (c) and 2-hydroxypropyl- $\beta$-cyclodextrin (d). 
The numbering of $\mathrm{C}$ atoms at naproxen and glucopyranose units of 2-hydroxypropyl- $\beta$-cyclodextrin was shown in Fig. 2, while the results of ${ }^{1} \mathrm{H}-\mathrm{NMR}$ analysis are given in Table 1.

The ${ }^{1} \mathrm{H}-\mathrm{NMR}$ analysis of the complex of naproxen:2-hydroxypropyl- $\beta$-cyclodextrin (Table 1 ) showed the presence of a multiplet at $\delta 7.0$ to $7.85 \mathrm{ppm}$ which originated from the proton of naphthalene in the naproxen structure, but of a significantly lower intensity. The signal at $\delta 1.52 \mathrm{ppm}$ assigned to protons in the position 3 of the $\mathrm{CH}_{3}$ groups of naproxen is also present in the ${ }^{1} \mathrm{H}$-NMR spectrum of the complex, but of lower intensity and shifted for +0.08 towards higher values of $\delta$ units. On the other hand, all of the signals originating from the protons of 2-hydroxypropyl- $\beta$-cyclodextrin glucopyranose units are present in the spectrum complex. The triplet at $\delta 3.975 \mathrm{ppm}$ assigned to $\mathrm{H}_{3}$ protons and the doublet at $\delta 1.125$ assigned to $\mathrm{H}_{9}$ protons from 2 -hydroxypropyl- $\beta$-cyclodextrin complex, are moved to higher values of $\delta$ units (Table 1 ), to +0.045 and +0.065 , respectively. The greatest displacement $(\Delta \delta=-0.1$ $\mathrm{ppm}$ ) in the spectrum of the complex showed the signals at $\delta 3.9 \mathrm{ppm}$, which corresponds to $\mathrm{H}_{6}$ protons of 2-hydroxypropyl- $\beta$-cyclodextrin glucopyranose units. Compared to naproxen and 2-hydroxypropyl- $\beta$-cyclodextrin, these movements in the ${ }^{1} \mathrm{H}-\mathrm{NMR}$ spectrum of the naproxen:2-hydroxypropyl- $\beta$-cyclodextrin complex indicated that there were non-covalent interactions between $\mathrm{H}_{3}$ protons of the guest molecules and $\mathrm{H}_{3}, \mathrm{H}_{6}$ and $\mathrm{H}_{9}$ protons of the host molecules, i.e., there was a formation of a supramolecular structure by the type of the inclusion.

In the FTIR spectrum of naproxen (Fig. 3, curve a) there was a wide absorption band of the medium intensity with the maximum at $3215 \mathrm{~cm}^{-1}$ attributed to the valence vibrations of $\mathrm{OH}$ groups from carboxylic acids, $v(\mathrm{OH})$.

The weak absorption band at $3002 \mathrm{~cm}^{-1}$ originated from $\mathrm{CH}$ valence vibrations of the aromatic part of the structure. In the FTIR spectrum of naproxen (Fig. 3, curve a), the characteristic band with a very high intensity and the maximum at $1727 \mathrm{~cm}^{-1}$ was the result of the valence vibration of $\mathrm{C}=\mathrm{O}$ group from carboxylic acids, $v(C=0)$, which is consistent with the investigations of other authors $[8,26]$. The weak band at 1416 $\mathrm{cm}^{-1}$ and the medium intensity band with the maximum at $1267 \mathrm{~cm}^{-1}$ in the spectrum were caused by coupling between $\mathrm{C}-\mathrm{O}$ valence vibrations and the $\mathrm{OH}$ deformation vibration in the plane. The existence of the condensed polycyclic aromatic structure (naphthaene) confirmed the bands of $\mathrm{C}=\mathrm{C}$ valence vibrations, $v(C=C)$, which occurred in the range of $1600-1450 \mathrm{~cm}^{-1}$ and were present in the spectrum with the maximal peaks at 1605, 1505, 1484 and $1458 \mathrm{~cm}^{-1}$. OH deformation vibrations in the plane, $\delta(\mathrm{OH})$, and out of the plane, $\gamma(\mathrm{OH})$, in the spectrum of naproxen (Fig. 3), provide the bands with the maximum at 1393 and 672 $\mathrm{cm}^{-1}$, respectively [7]. The medium strength band at<smiles>CC(C(=O)O)c1ccc2cc(OC#N)ccc2c1</smiles>

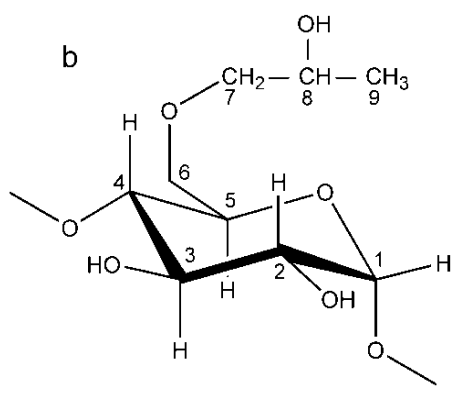

Figure 2. The numbering of $C$ atoms with naproxen (a) and glucopyranosyl unit 2-hydroxypropyl- $\beta$-cyclodextrin (b).

Table 1. Chemical shifts ( $\delta / \mathrm{ppm})$ of protons in the ${ }^{1} \mathrm{H}$-NMR spectrum of naproxen, 2-hydroxypropyl- $\beta$-cyclodextrin and inclusion complex naproxen:2-hydroxypropyl- $\beta$-cyclodextrin and changes in chemical shift $(\Delta \delta / p p m) ; s-$ singlet, $d$-doublet, dd-doublet of doublets, $t$-triplet, $q$-quartet, $m$ - multiplet, $H P$ - $\beta$-CD-2-hydroxypropyl- $\beta$-cyclodextrin

\begin{tabular}{lccc|cccc}
\hline C-atom & Naproxen & Complex & $\Delta \delta$ & C-atom & HP- $\beta-C D$ & complex & $\Delta \delta$ \\
\hline $1^{\prime}$ & $7.25(s, 1 \mathrm{H})$ & $7.25(s, 1 \mathrm{H})$ & - & 1 & $5.15(d, 1 \mathrm{H})$ & $5.15(d, 1 \mathrm{H})$ & - \\
2 & $3.84(q, 1 \mathrm{H})$ & - & - & 2 & $3.62(t, 1 \mathrm{H})$ & $3.62(t, 1 \mathrm{H})$ & - \\
3 & $1.52(d, 3 \mathrm{H})$ & $1.6(d, 3 \mathrm{H})$ & +0.08 & 3 & $3.975(t, 1 \mathrm{H})$ & $4.02(t, 1 \mathrm{H})$ & +0.045 \\
$3^{\prime}$ & $7.13(d d, 1 \mathrm{H})$ & - & - & 4 & $3.46-3.53(\mathrm{~m}, 1 \mathrm{H})$ & - & - \\
$4^{\prime}$ & $7.71(d, 1 \mathrm{H})$ & $7.71(d, 1 \mathrm{H})$ & - & 5 & - & - & - \\
$5^{\prime}$ & $7.68(s, 1 \mathrm{H})$ & $7.68(s, 1 \mathrm{H})$ & - & 6 & $3.9(s, 2 \mathrm{H})$ & $3.8(s, 2 \mathrm{H})$ & -0.1 \\
$7^{\prime}$ & $7.4(d d, 1 \mathrm{H})$ & $7.4(d d, 1 \mathrm{H})$ & - & 7 & - & - & - \\
$8^{\prime}$ & $7.76(d, 1 \mathrm{H})$ & $7.76(d, 1 \mathrm{H})$ & - & 8 & - & - & - \\
$11^{\prime}$ & $3.92(s, 3 \mathrm{H})$ & - & - & 9 & $1.125(d, 3 \mathrm{H})$ & $1.19(d, 3 \mathrm{H})$ & +0.065 \\
\hline
\end{tabular}




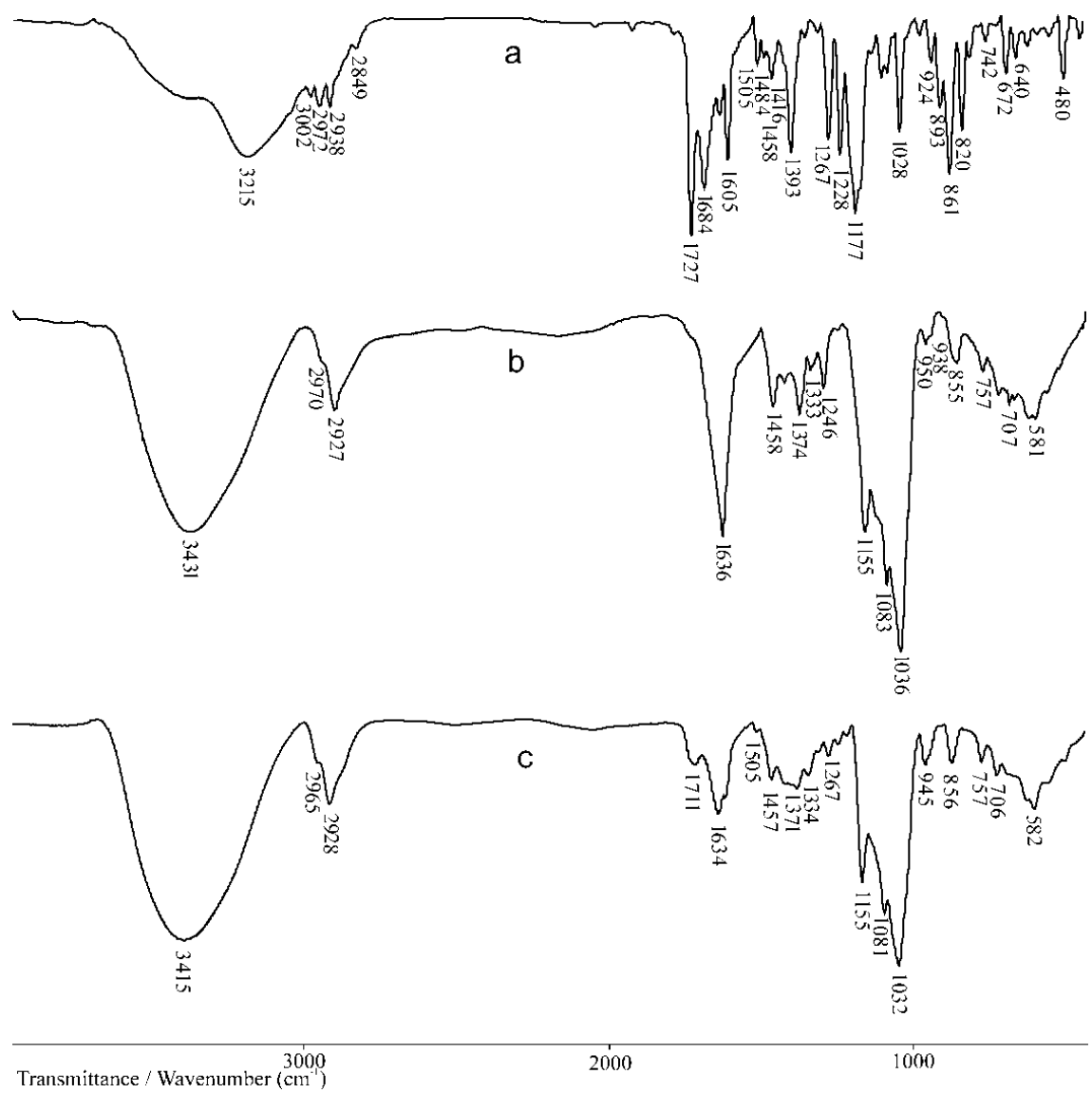

Figure 3. FTIR spectrum of naproxen (a), 2-hydroxypropyl- $\beta$-cyclodextrin (b) and inclusion complex of naproxen:2-hydroxypropyl- $\beta$ -cyclodextrin (c).

$924 \mathrm{~cm}^{-1}$, which also originating from the $\mathrm{OH}$ group out-of-plane deformation vibration, indicates the possibility of dimeric forms of naproxen.

The FTIR analysis of the spectrum of 2-hydroxypropyl- $\beta$-cyclodextrin (Fig. 3, curve b) showed the characteristic wide band of high intensity with the maximum at $3431 \mathrm{~cm}^{-1}$, which originated from the valence vibration of $\mathrm{OH}$ groups, $\mathrm{v}(\mathrm{OH})$. The bands of valence vibrations of $\mathrm{CH}$ groups, $\mathrm{v}(\mathrm{CH})$, in the of 2-hydroxypropyl- $\beta$-cyclodextrin were present at 2970 and $2927 \mathrm{~cm}^{-1}$, while the bands of deformation vibrations in the plane, $\delta(\mathrm{CH})$, appeared at 1458 and $1374 \mathrm{~cm}^{-1}$. The intensive band with the maximum at $1155 \mathrm{~cm}^{-1}$ was the result of valence vibrations of $\mathrm{C}-\mathrm{O}-\mathrm{C}$ bond, and this is the characteristic of saturated cyclic ethers. In the range of $1200-1000 \mathrm{~cm}^{-1}$ there was a complex band with the maxima at 1155, 1083 and $1036 \mathrm{~cm}^{-1}$ resulting from the coupling of asymmetric valence vibrations $\mathrm{C}-\mathrm{O}, \mathrm{C}-\mathrm{O}-\mathrm{C}, \mathrm{C}-\mathrm{C}-\mathrm{O}$ and $\mathrm{C}-\mathrm{C}-\mathrm{C}$ bonds. In the FTIR spectrum of the host (Fig. 3 , curve b) the existence of glucopyranose units was confirmed by the bands in the area of $700-1000 \mathrm{~cm}^{-1}$, whereas the $\mathrm{C} 1$ of chairs conformation indicated the bands appearing in the spectrum at 950 and $855 \mathrm{~cm}^{-1}$.
The analysis of the FTIR spectrum of the inclusion complex naproxen:2-hydroxypropyl- $\beta$-cyclodextrin (Fig. 3 , curve c) showed that there was a difference in comparison to the FTIR spectra of naproxen (Fig. 3, curve a) and 2-hydroxypropyl- $\beta$-cyclodextrin (Fig. 3, curve b). The band of $\mathrm{OH}$ group valence vibrations, $\mathrm{v}(\mathrm{OH})$, from 2 -hydroxypropyl- $\beta$-cyclodextrin in the spectrum of the complex (Fig. 3, curve c) at $3415 \mathrm{~cm}^{-1}$ was shifted to lower wave numbers by 16 units, compared to the position of the same band in the spectrum of the host. This band covers the band of $\mathrm{OH}$ group valence vibrations from carboxyl groups of naproxen. In the spectrum of the complex, the valence vibrations of $\mathrm{C}=\mathrm{O}$ group of naproxen provided a low intensity band with the maximum at $1711 \mathrm{~cm}^{-1}$, the centroid of which was shifted towards smaller wave numbers by 16 units, compared to naproxen. This shift may indicate a noncovalent interaction of the host molecule with the guest molecule. In the spectrum of the complex, there was a characteristic band from the condensed polycyclic aromatic structure of naproxen, as a single band of low intensity which occurred at $1505 \mathrm{~cm}^{-1}$. In the spectrum of the complex there was also a low intensity band with the maximum at $1267 \mathrm{~cm}^{-1}$, which was the result of coupling between the valence vibration of $\mathrm{C}-\mathrm{O}$ 
groups and the deformation vibrations of $\mathrm{OH}$ groups from naproxen. Compared to the same bands in 2-hydroxypropyl- $\beta$-cyclodextrin spectrum $(2970$ and 2927 $\mathrm{cm}^{-1}$ ), the medium intensity band with the maxima at 2965 and $2928 \mathrm{~cm}^{-1}$, which were attributed to $\mathrm{CH}$ valence vibrations, showed a movement of the centroid towards smaller wave numbers for 5 and 1 units, respectively. This shift may be the result of establishing a hydrogen bond between the $\mathrm{CH}$ groups of complexing agents which are proton donors and the guest molecules.

The differences in the FTIR spectra indicated the formation of supramolecular structures by the type of inclusions and they were in compliance with the investigations of ${ }^{1} \mathrm{H}-\mathrm{NMR}$ and XRD analysis.

Marrota et al. studied the photosensitivity of naproxen and kinetics of photodegradation. In the aqueous medium, 2-acetyl-6-methoxynaphthalen and 1-(6-methoxy-2-naphthyl)ethanol were determined as the main photodegradation products [27]. The scheme of photolytic degradation of naproxen is given in Fig. 4 [23].

Naproxen is a photosensitive molecule that, in the presence of oxygen, gives two degradation products, aromatic alcohol and ketone (Fig. 4). By decarboxylation of naproxen (I) a product is formed (II), i.e., 1-(6-methoxy-2-naphthyl) ethanol. By further oxidation of the resulting alcohol the photodegradation product (III), 2-acetyl-6-methoxynaphthalen was obtained, which may be derived directly from naproxen. By photodegradation of naproxen, the molecules with higher toxicity of naproxen which reduce the pharmacological activity and the safety of the drug application were obtained [23].

In these investigations the photostability of naproxen in the pure state and in the complex was monitored by FTIR spectroscopy during 30 days of exposure to daylight. The structure change of naproxen under the influence of daylight was monitored using UV-Vis spectrophotometry. The results of this testing are given in Fig. 5.

In the UV-Vis spectrum of naproxen, which was not exposed to daylight (Fig. 5, curve a), three absorption maxima at 208, 256 and $328 \mathrm{~nm}$ originating from the $\pi \rightarrow \pi^{*}$ transitions of naphthalene were found. The
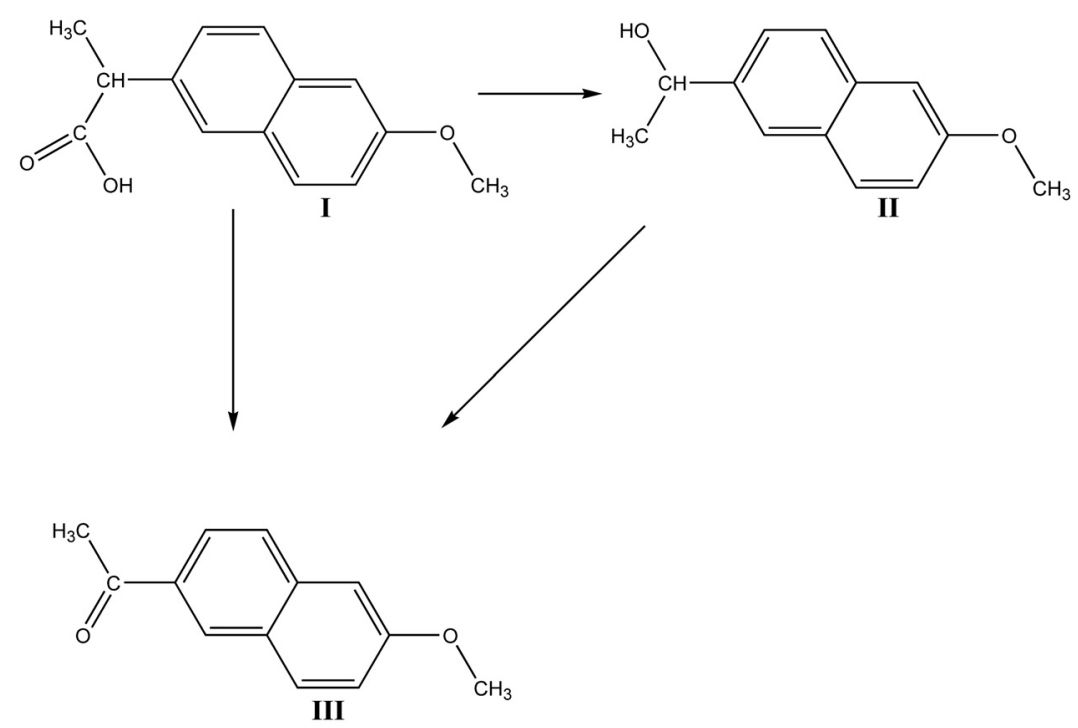

Figure 4. Photodegradation route of naproxen.

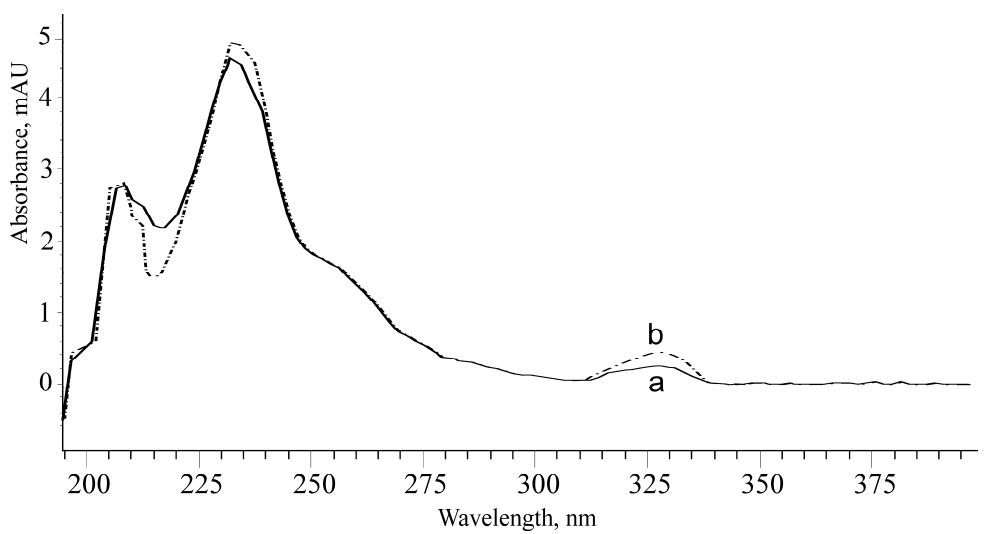

Figure 5. UV-Vis spectrum of naproxen not exposed to daylight (a) and after exposure to 30 days (b). 
presence of $\mathrm{C}=\mathrm{O}$ of carboxyl group in naproxen which originated from the $n \rightarrow \pi^{*}$ transitions was confirmed by the maximum absorbance at $232 \mathrm{~nm}$. In the UV-Vis spectrum of naproxen which was exposed to daylight for 30 days (Fig. 5, curve b) the absorption maxima at the same wavelengths as naproxen were observed but of a bit greater intensity. These maxima corresponded to $\pi \rightarrow \pi^{*}$ and $n \rightarrow \pi^{*}$ transitions of naphthalene and keto groups, respectively, which means that these functional groups were retained in the photodegradation product of naproxen. Based on the UV-Vis analysis it can be concluded that under the influence of daylight naproxen most probably formed aromatic ketone, 2-acetyl-6-methoxynaphthalen (III), which is in accordance with the studies of other authors [23].

FTIR spectra naproxen and naproxen which was exposed to daylight for a period of 30 days are given in Fig. 6.

The comparative analysis of the FTIR spectra of naproxen (Fig. 6, curve a) and naproxen exposed to daylight (Fig. 6, curve b) showed that in the spectrum of naproxen exposed to daylight for 15 days (Fig. 6, curve b) bands at 3213, 1393 and $924 \mathrm{~cm}^{-1}$ from the $\mathrm{OH}$ valence and deformation vibration were observed, which were less intensive than in the spectrum of naproxen (Fig. 6, curve a). The centroid of the band attributed to valence vibrations of $\mathrm{OH}$ group $\left(3213 \mathrm{~cm}^{-1}\right)$ in the spectrum of naproxen which was exposed to daylight for 15 days was shifted to lower wave numbers by 2 units. These changes in the spectrum might indicate that a certain extent of naproxen was succumbed to photodegradation.

It is evident that there is no loss of the band from $\mathrm{C}=\mathrm{O}$ valence vibrations in the spectrum of naproxen which is exposed to daylight for 15 days, which leads to the conclusion that in the structure of photodegradation products a keto group, $\mathrm{C}=\mathrm{O}$ is still present. According to the studies of other researchers this corresponds to the photodegradation products III [23] (Fig. 4). The spectrum of naproxen which is continuously exposed to daylight for 30 days (Fig. 6, curve c) showed the additional reduction of the band intensity with the maxima at 3216, 1393, 924 and $672 \mathrm{~cm}^{-1}$, while the band of the $\mathrm{C}=\mathrm{O}$ group at $1727 \mathrm{~cm}^{-1}$ remained unchanged, compared to the same band in the spectrum of naproxen and naproxen exposed to daylight for 15 days. Based on the obtained results it can be suggested that photodegradation is heading towards the product III, i.e., 2-acetyl-6-methoxynaphthalen, which is consistent with the UV-Vis analysis in this paper.

In order to determine the stability of naproxen in the inclusion complex with 2-hydroxypropyl- $\beta$-cyclodextrin, the change of the bands using the FTIR spectra was monitored for 30 days. Periodical recording was carried out and the results are shown in Fig. 7.

Comparing the FTIR spectra of the inclusion complex which was not exposed to daylight (Fig. 7, curve a) and the inclusion complex which was exposed to daylight for 30 days (Fig. 7, curve b), it is evident that there is no loss of the bands as well as their changes in
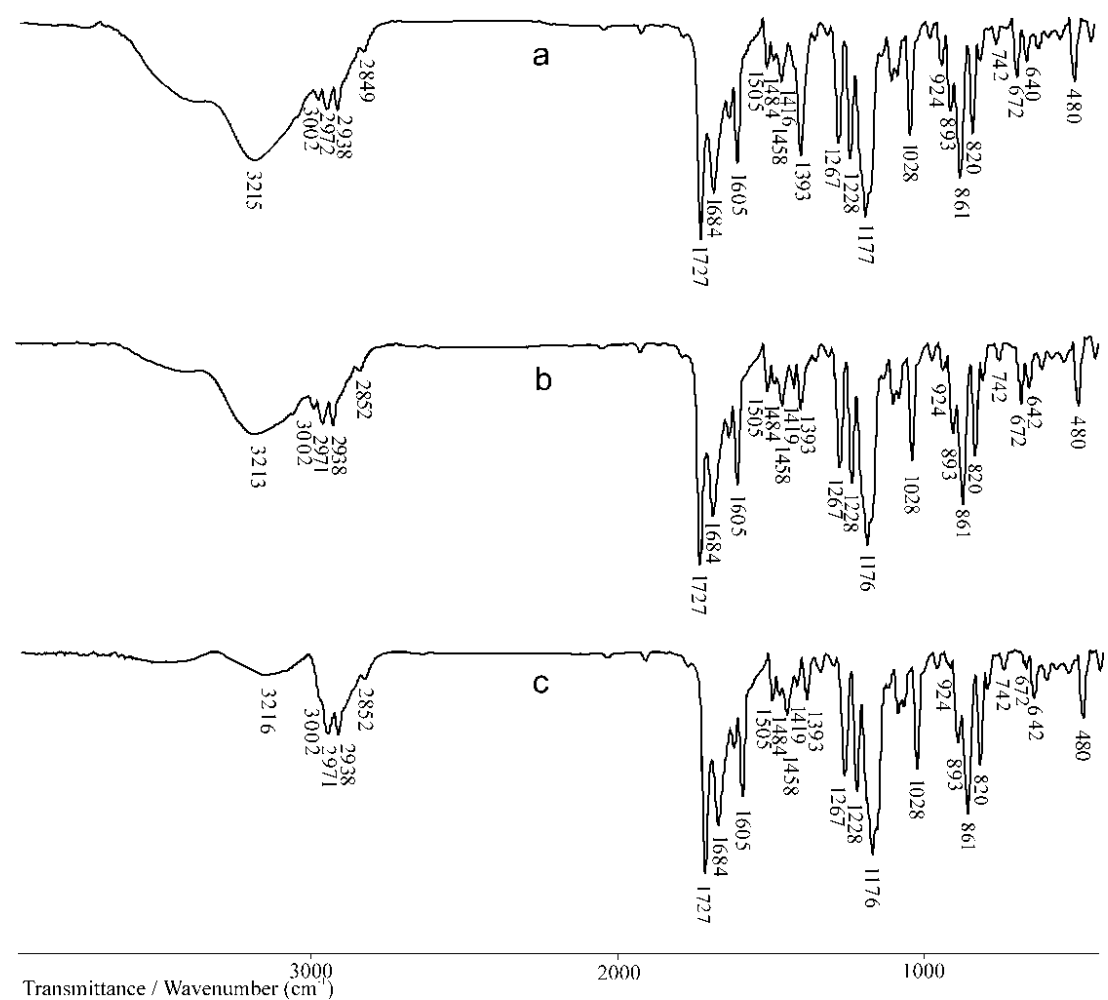

Figure 6. FTIR spectrum of naproxen not exposed to daylight (a) and after exposure to daylight for 15 (b) and 30 days (c). 

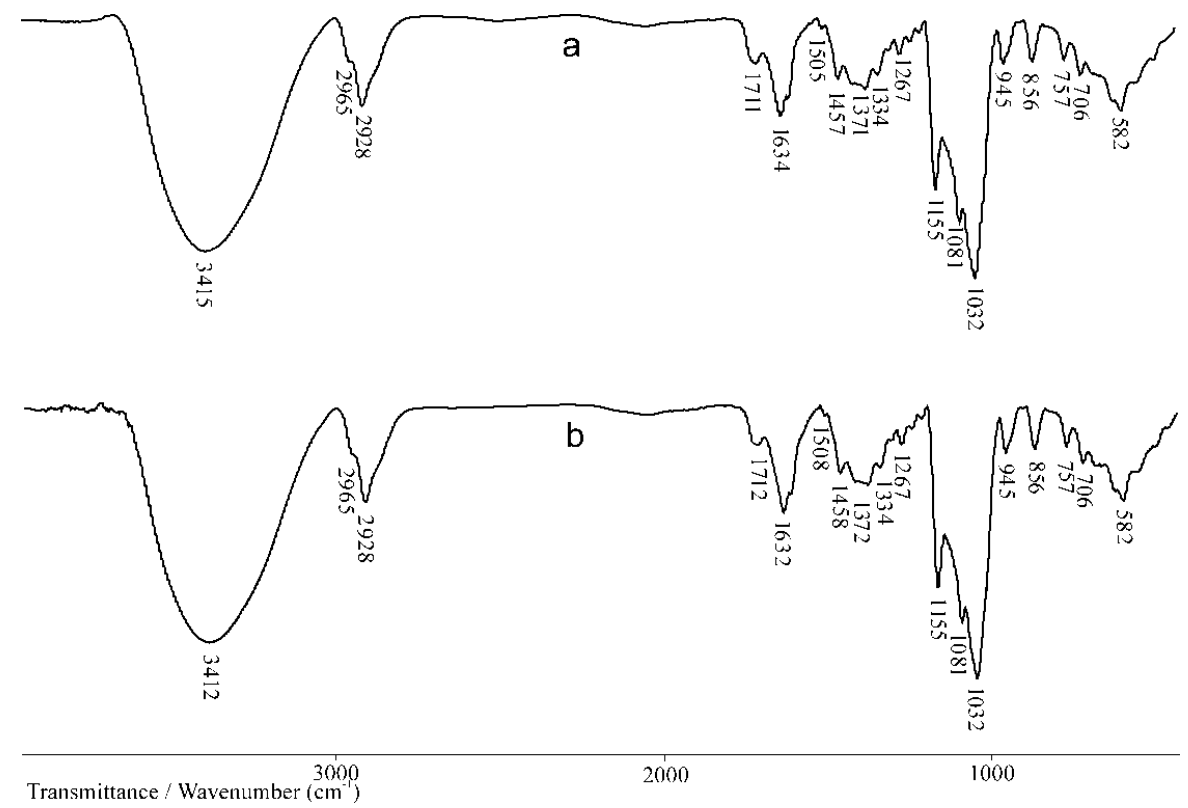

Figure 7. FTIR spectrum of the inclusion complex of naproxen:2-hydroxypropyl- $\beta$-cyclodextrin not exposed to daylight (a) and after exposure to 30 days (b).

the intensity and position or the appearance of new bands. These results indicate that the inclusion complex of naproxen:2-hydroxypropyl- $\beta$-cyclodextrin is photostabile and preserves naproxen for 30 days, while the uncomplexed naproxen is largely degraded for the same period.

\section{CONCLUSION}

The molecular inclusion complex was prepared by the co-precipitation method in the solid state at 1:1 molar ratio of the reactants. The loss of peaks in the complex naproxen:2-hydroxypropyl- $\beta$-cyclodextrin at $6.5,13.4,16.6,18,19.9,22.1,23.9$ and $28.2^{\circ}$, which is a characteristic of naproxen in the XRD diffractogram, indicates that the drug is sheltered from the $X$-rays and shows that there was an inclusion of the drug in the hydrophobic cavity of 2-hydroxypropyl- $\beta$-cyclodextrin. Chemical shifts of the signals from $\mathrm{H}_{3}, \mathrm{H}_{6}$ and $\mathrm{H}_{9}$ protons of glucopyranose units, as well as the signals of protons from $\mathrm{CH}_{3}$ group of naproxen at position 3 in the ${ }^{1} \mathrm{H}-\mathrm{NMR}$ spectrum of the complex, suggest the presence of non-covalent interactions of the host molecule with the guest molecule. The loss of characteristic bands in the FTIR spectrum of naproxen:2-hydroxypropyl- $\beta$-cyclodextrin also demonstrates the formation of supramolecular structures, which is consistent with the results of the previous analysis. The results of the investigation of photodegradation of naproxen by FTIR and UV-Vis methods show that naproxen is photounstable and that the main degradation product is the aromatic ketone, 2-acetyl-6-methoxynaphthalen (III). The inclusion complex of naproxen:2-hydroxypropyl- $\beta$ - -cyclodextrin showed the increased photostability of naproxen, compared to the uncomplexed naproxen.

\section{Acknowledgement}

This work is a part of the research done within the project TR 34012. The authors would like to thank to the Ministry of Education, Science and Technological Development, Republic of Serbia.

\section{REFERENCES}

[1] A. Bruke, E.M. Smzth, G.A. FitzGerald, in: L. Brunton, J. Lazo, K. Parker (Eds.), Goodman \& Gilman's The pharmacological basis of therapeutics, $11^{\text {th }}$ ed., The McGraw-Hill Companies, New York, 2005, pp. 687-733.

[2] P. Mura, N. Zerrouk, N. Mennini, F. Maestrelli, C. Chemtob, Development and characterization of naproxen-chitosan solid systems with improved drug dissolution properties, Eur. J. Pharm. Sci. 19 (2003) 67-75.

[3] N. Zerrouk, N. Mennini, F. Maestrelli, C. Chemtob, P. Mura, Comparison of the effect of chitosan and polyvinylpyrrolidone on dissolution properties and analgesic effect of naproxen, Eur. J. Pharm. Biopharm. 57 (2004) 93-99.

[4] P. Mura, F. Maestrelli, M. Cirri, Ternary systems of naproxen with hydroxypropyl- $\beta$-cyclodextrin and aminoacids, Eur. J. Pharm. Sci. 260 (2003) 293-302.

[5] M. Maghsoodi, D. Hassan-Zadeh, M. Barzegar-Jalali, A. Nokhodchi, G. Martin, Improved Compaction and Packing Properties of Naproxen Agglomerated Crystals Obtained by Spherical Crystallization Technique, Drug Dev. Ind. Pharm. 33 (2007) 1216-1224.

[6] G-V. Jin, X.Y. Ji, J.S. Choi, Preparation of NaproxenLoaded Poly(ethylene oxide- $\beta$-methacrylic acid) Micelle 
and Its pH-dependent Drug Release Behavior, Bull. Korean Chem. Soc. 30 (2009) 931-934.

[7] S. Bogdanova, I. Pajeva, P. Nikolova, I. Tsakovska, B. Müller, Interactions of Poly(vinylpyrrolidone) with Ibuprofen and Naproxen: Experimental and Modeling Studies, Pharm. Res. 22 (2005) 806-815.

[8] R. Nair, N. Nyamweya, S. Gönen, L.J. Martínez-Miranda, S.W. Hoag, Influence of various drugs on the glass transition temperature of poly(vinylpyrrolidone): a thermodynamic and spectroscopic investigation, Int. J. Pharm. 225 (2001) 83-96.

[9] N. Erdena, N. Çelebi, A study of the inclusion complex of naproxen with $\beta$-cyclodextrin, Eur. J. Pharm. Sci. 48 (1988) 83-89.

[10] J. Wang, I.M. Warner, Studies of the Naproxen: $\beta$-Cyclodextrin Inclusion Complex, Microchem. J. 48 (1993) 229-239.

[11] S.E. Brown, J.H. Coates, C.J. Easton, S.F. Lincoln, Y. Luo, A.K.W. Stephens, Cyclodextrin Inclusion Complexes of Two Non-Steroidal Antiinflammatory Drugs and of an Analgesic Drug, Aust. J. Chem. 4 (1991) 855-862.

[12] V. Nikolić, Lj. Nikolić, M. Stanković, A. Kapor, M. Popsavin, D. Cvetković, A molecular inclusion complex of atenolol with 2-hydroxypropyl- $\beta$-cyclodextrin; the production and characterization thereof, J. Serb. Chem. Soc. 72 (2007) 737-746.

[13] R. Ficarra, P. Ficarra, M.R. Di Bella, D. Raneri, S. Tommasini, M.L. Calabro, M.C. Gamberini, C. Rustichelli, Study of $\beta$-blockers/ $\beta$-cyclodextrins inclusion complex by NMR, DSC, X-ray and SEM investigation, J Pharm Biomed. Anal. 23 (2000) 33-40.

[14] R. Ficarra, P. Ficarra, M.R. Di Bella, D. Raneri, S. Tommasini, M.L. Calabro, A. Villari, S. Coppolino, Study of the inclusion complex of atenolol with $\beta$-cyclodextrins, J. Pharm. Biomed. Anal. 23 (2000) 232-236.

[15] V. Nikolić, D. Ilić, Lj. Nikolić, M. Stanković, M. Cakić, Lj. Stanojević, A. Kapor, M. Popsavin, The protection of Nifedipin from photodegradation due to complex formation with $\beta$-cyclodextrin, Cent. Eur. J. Chem. 8 (2010) 744-749.

[16] J. Mielcarek, Photochemical stability of the inclusion complexes of nicardipine with $\alpha-, \quad \gamma$-cyclodextrin, methyl- $\beta$-cyclodextrin, hydroxypropyl- $\beta$-cyclodextrins in the solid state and in solution, Pharmazie 51 (1996) 477-479.
[17] K.L.A. Chan, S.G. Kazarian, FTIR spectroscopic imaging of dissolution of a solid dispersion of nifedipine in poly(ethylene glycol), Mol. Pharm. 1 (2004) 331-335.

[18] A. Kapor, V. Nikolić, Lj. Nikolić, M. Stanković, M. Cakić, Lj. Stanojević, D. Ilić, Inclusion complexes of amlodipine besylate and cyclodextrins, Cent. Eur. J. Chem. 8 (2010) 834-841.

[19] J. Mielcarek, A. Czernielewska, B. Czarczynska, Inclusion Complexes of Felodipine and Amlodipine with Methyl- $\beta$ cyclodextrin, J. Incl. Phenom. Macrocycl. Chem. 54 (2006) 17-21.

[20] V. Nikolić, M. Stanković, A. Kapor, Lj. Nikolić, D. Cvetković, J. Stamenković, Allylthiosulfinate; $\beta$-cyclodextrin inclusion complex: preparation, characterization and microbiological activity, Pharmazie 59 (2004) 845-848.

[21] M.C.B. Lira, M.S. Ferraz, D.G.V.C. da Silva, M.E. Cortes, K.I. Teixeria, N.P. Caetano, R.D. Sinisterra, G. ponchel, N.S. Santos-Magalhes, Inclusion complex of usnic acid with $\beta$-cyclodextrin: characterization and nanoencapsulation into liposomes, J. Incl. Phenom. Macrocycl. Chem. 64 (2009) 215-224.

[22] L.J. Martínez, J.C. Scaiano, Characterization of the transient intermediates generated from the photoexcitation of nabumetone: a comparison with naproxen, Photochem. Photobiol. 68 (1998) 646-651.

[23] W. Cory, A. DeSantis, C. Ulmer, Photodegradation of Naproxen and Ibuprofen and the Formation of Ecotoxic Photoproducts in Natural Water Systems, IWA Specialty Conference on natural Organic Matter, Costa Mesa, CA, July 27-29, 2011.

[24] V. Nikolić, S. Ilić-Stojanović, Lj. Nikolić, M. Cakić, A. Zdravković, A. Kapor, M. Popsavin, Photostability of piroxicam in the inclusion complex with 2-hydroxypropyl- $\beta$-cyclodextrin, Hem. Ind. 68 (2014) 107-116.

[25] V. Nikolić, M. Stanković, Lj. Nikolić, G. Nikolić, S. IlićStojanović, M. Popsavin, S. Zlatković, T. Kundaković, Inclusion complexes with cyclodextrin and usnic acid, J. Incl. Phenom. Macrocycl. Chem. 76 (2013) 173-182.

[26] N. Tiong, A.A. Elkordy, Effects of liquisolid formulations on dissolution of naproxen, Eur. J. Pharm. Biopharm. 73 (2009) 373-384.

[27] R. Marotta, D. Spasiano, I. Di Somma, R. Andreozzi,: Photodegradation of naproxen and its photoproducts in aqueous solution at $254 \mathrm{~nm}$ : A kinetic investigation. Water Res. 47 (2013) 373-383. 


\section{IZVOD}

\section{POBOLŠANA FOTOSTABILNOST NAPROKSENA U INKLUZIONOM KOMPLEKSU SA 2-HIDROKSIPROPIL- $\beta$-CIKLODEKSTRINOM}

Snežana S. llić-Stojanović ${ }^{1}$, Vesna D. Nikolić ${ }^{1}$, Ljubiša B. Nikolić ${ }^{1}$, Aleksandar S. Zdravković ${ }^{2}$, Agneš J. Kapor ${ }^{3}$, Mirjana M. Popsavin ${ }^{4}$, Slobodan D. Petrović ${ }^{5}$

${ }^{1}$ Univerzitet u Nišu, Tehnološki fakultet, Leskovac, Srbija

${ }^{2}$ Visoka strukovna škola za tekstil, Leskovac, Srbija

${ }^{3}$ Univerzitet u Novom Sadu, Prirodno-matematički fakultet, Departman za Fiziku, Novi Sad, Srbija

${ }^{4}$ Univerzitet u Novom Sadu, Prirodno-matematički fakultet, Departman za Hemiju, Novi Sad, Srbija

${ }^{5}$ Univerzitet u Beogradu, Tehnološko-Metalurški fakultet, Beograd, Srbija

\section{(Naučni rad)}

Naproksen, (+)-(S)-2-(6-metoksinaftalen-2-il)propionska kiselina, je derivat 2-arilpropionske kiseline (profena) iz grupe nesteroidnih antiinflamatornih lekova koji u terapijskim dozama smanjuje biosintezu prostaglandina i snižava povišenu telesnu temperaturu. Ovaj slabo rastvoran i fotoosetljiv molekul se transformiše pod uticajem svetlosti dajući farmakološki neaktivne proizvode. Cilj ovog rada je priprema inkluzionog kompleksa naproksena sa 2-hidroksipropil- $\beta$-ciklodekstrinom (HP- $\beta$-CD) u cilju poboljšanja fizičko-hemijskih svojstava naproksena. Molekulski inkluzioni kompleks naproksena i HP- $\beta$-CD pripremljen je metodom koprecipitacije u čvrstom stanju u molskom odnosu 1:1. Za strukturnu karakterizaciju kompleksa, kompleksirajućeg agensa, odgovarajuće fizičke smeše i naproksena, korišćene su metode protonske nuklearne magnetne rezonance $\left({ }^{1} \mathrm{H}-\mathrm{NMR}\right)$, difrakcije rendgenskih zraka (XRD) i infracrvene spektrofotometrije sa Furijeovom transformacijom (FTIR). FTIR i UV-Vis metode korišćene su za analizu fotoosetljivih grupa naproksena $u$ čistom i kompleksiranom obliku radi ispitivanja uticaja na fotostabilnost naproksena. Difraktogram inkluzionog kompleksa naproksen:2-hidroksipropil- $\beta$-ciklodekstrin ne sadrži pikove koji su karakteristični za difraktograme naproksena i HP- $\beta-C D$. Ovo ukazuje da je naproksen zaklonjen u šupljine domaćina prilikom molekularne inkapsulacije. Odsustvo karakterističnih pikova naproksena u FTIR spektru kompleksa ukazuje na formiranje supramolekularne strukture po tipu inkluzije. Hemijska pomeranja $u^{1} \mathrm{H}-\mathrm{NMR}$ spektru nakon inkluzije naproksena $\mathrm{u}$ šupljine $\mathrm{HP}-\beta-\mathrm{CD}$, posebno $\mathrm{H}_{3}, \mathrm{H}_{6}$ i $\mathrm{H}_{9}$ protona i vodonika iz $\mathrm{CH}_{3} \mathrm{u}$ HP- $\beta$-CD takođe ukazuju na formiranje molekulskog inkluzionog kompleksa. Ispitivanje fotostabilnosti naproksena, pomoću UV-Vis metode, ukazuje na degradaciju do aromatičnog ketona, 2-acetil-6-metoksinaftalena. FTIR analiza je pokazala da degradacija naproksena počinje nakon 15 dana izlaganja dnevnoj svetlosti i da je molekularnom inkapsulacijom on zaštićen od fotodegradacije za vremenski period od 30 dana.
Ključne reči: Naproksen • Fotodegradacija • 2-hidroksipropil- $\beta$-ciklodekstrin • Inkluzioni kompleks 